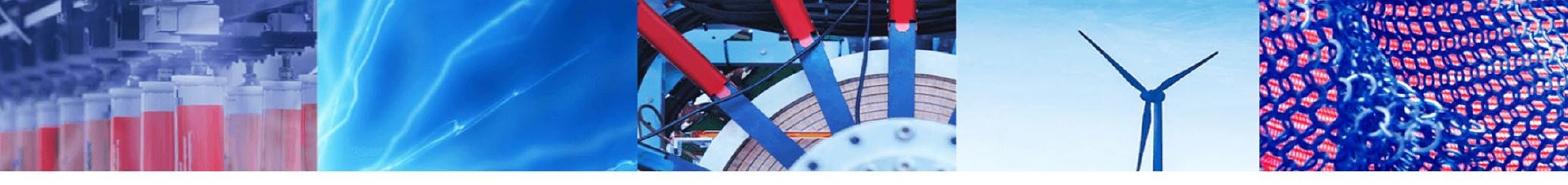

Research Article

\title{
The interactive pedological-hydrological processes and environmental sensitivity of a tropical isolated wetland in the Brazilian Cerrado
}

\author{
Lucas Moreira Furlan ${ }^{1}$. Vania Rosolen ${ }^{1}$. César Augusto Moreira ${ }^{1} \cdot$ Guilherme Taitson Bueno ${ }^{2}$. \\ Manuel Eduardo Ferreira ${ }^{2}$
}

Received: 10 September 2020 / Accepted: 6 January 2021 / Published online: 18 January 2021

(c) The Author(s) 2021 OPEN

\begin{abstract}
In seasonal flooding isolated wetlands, the degree of wetness suggests a close synergy between soil processes, landscape evolution and hydrology along space and time. Until now, that subject has received insufficient attention despite natural wetlands supply essential environmental services to society and are surrounded by intensive agriculture that uses agrochemicals and fertilizers in their management. The objectives of this study were to propose an infiltration architecture model based on local surface and subsurface water-fluxes in isolated wetland embedded in lateritic plateau covered by savanna and qualify the environmental sensitivity as an area of aquifer recharge. Grain size, soil bulk density, and hydraulic conductivity were determined in five profiles in a soil catena. Unmanned Aerial Vehicle high-resolution images were obtained to generate a digital elevation model and discriminate areas with different vegetation, water accumulation, and environmental sensitivity. Electrical tomography was performed to unveil the soil architecture and infiltration. The soils (Plinthosols) developed on aquic conditions determine the linkage between the surface-subsurface hydrodynamics with the soil's physical properties. We have identified vertical and lateral water-flows in the soil architecture. Vertical flow occurs exclusively at the center, where the wetland is characterized as a recharge zone. Lateral flow towards the borders characterizes a discharge zone. The recharge zone is a depression surrounded by crops; therefore, it is a point of high environmental sensitivity. This hydrodynamic model is essential to support studies related to the dispersion of contaminants since soybean agriculture dominates the whole area of well-drained soils in the Brazilian Cerrado.
\end{abstract}

Keywords Hydraulic conductivity · Bulk density · Aquic soil · Resistivity · Aerial photogrammetry · Aquifer recharge

\section{Introduction}

Soil hydraulic properties such as soil saturated hydraulic conductivity are critical components of the Earth's Critical Zone, and they are helpful to understand the interactions between soil functions and water cycle processes [1]. The physical soil properties are intimately related to the mobility and transport of solutes and contaminants, i.e., pesticides and trace metals. At the same time, the quality of freshwater is closely related to biogeochemical processes in soil and water environments in the Critical Zone $[2,3]$. Thus, interactions between soil and water are intimate and complex because of their heterogeneity, webs of interactions, wide-ranging scales, and self-organizing features [4]. In this sense, soil architecture and soil hydraulic properties vary in space and time-producing nonlinear flows of mass and energy and reflect a sequence of occurred events on the landscape [5], that can impact not only geomorphological evolution but also the quantity and quality of water available in the ecosystem.

\footnotetext{
$\triangle$ Lucas Moreira Furlan, lucasmfurlan@gmail.com | 1 Geosciences and Exact Sciences Institute (IGCE), São Paulo State University (UNESP), Av. 24A, 1515, Bela Vista, CP 178, Rio Claro, São Paulo State 13506-900, Brazil. ${ }^{2}$ Instituto de Estudos Sócio-Ambiental (IESA), Federal University of Goiás (UFG), Av. Esperança, s/n - Chácaras de Recreio Samambaia, Goiânia, Goiás State 74690-900, Brazil.
} 
In the mature tropical landscape characterized by deeply weathered bedrock and soil profiles, very complex hydropedological domains occur and they are associated with long-term tectonic stability, well-preserved relief, and persistence of paleoclimatic cycles along with the geological history [6]. External (i.e., paleoclimate) and internal (i.e., clay eluviation) soil processes operate actively inducing a substantial change in soil moisture regime, spatial and temporal patterns of water flow, and water storage [7]. The results are soil covers exhibiting a complex vertical and lateral organization that reflects the formation and transformation of soils and saprolites generated by a distinct environment [8]. As far as soil and saprolite develop, structures and soil fabrics superimpose in layers in a saturated and non-saturated domain. Soil aggregation and aggregate disruption in wet-dry cycles control the soil pore system and consequently physical and hydraulic properties that change in response to soil architecture [9]. In the aquic moisture regime, the soil fabric changes due to the instability of the bonding clay-iron [10]. The response is vertical subsidence of land surface changing the hydrology of soils in the slope [11]. This process represents the evolution of the wetlands in the study area (Triâgulo Mineiro plateau, Brazil).

The process is active and it is determining the development of a wetland through time [12] and the aquic moisture regime generates a complex flow path of water in and out of the wetland area [13]. The soil hydrology that characterizes wetlands in the landscape is a contemporary process so the assumption is that its formation and evolution are changing the path and the direction of water flows in soil and slope. In the west of Minas Gerais State (Brazil), the flat plateau covered by savanna shows a dense distribution of ephemeral-isolated wetlands characterized by depressed topography embedded within a continuum with well-drained lateritic soil. These wetlands correspond to natural seasonal water-reservoirs, flooded during the rainy season, and dry out during the drought. The hydrodynamics model in the wetlands of the Cerrado biome is unknown, regardless be the key for understanding the dynamics and linkages between pedological processes and hydrological functions, necessary to evaluate theirs benefits at the catchment and landscape evolution [14].

Seasonal flooding of ephemeral wetlands depends on the rainfall and on the high internal morphology complexity. The internal domain is due to a distinct degree of wetness along space and time, reinforcing the system complexity between soil and hydrology, which has received little attention [15, 16]. Natural wetlands have enormous value to society because the storage of water and organic carbon improve water quality, recharge groundwater aquifer, and support rich biodiversity [17-19]. Also, natural wetlands have proven to be capable of improving the water quality and regulating the bioavailability of contaminants [20]. Non-point sources of chemical substances derived from runoff of surrounded agriculture areas will become a potential threat to the water quality of the aquatic systems increasing pollutants in wetlands owing to heavy metals' toxicity, persistence, bio-accumulative nature, vast sources, and non-degradability [21].

The objectives of this study were to (1) disclose water flow in an isolated wetland embedded in lateritic plateau covered by savanna and propose a model of the infiltration architecture, and (2) qualify and evaluate the environmental sensitivity of the isolated wetland as an area of aquifer recharge.

\section{Material and methods}

\subsection{Study site}

The study was conducted in a wetland located in the upper reach of the Rio Claro catchment (Rio Claro River), at an altitude of $966 \mathrm{~m}$ a.s.l. $-19^{\circ} 28^{\prime} 08^{\prime \prime} \mathrm{S}, 47^{\circ} 48^{\prime} 20^{\prime \prime}$ W, West of Minas Gerais State in Brazil, in the municipality of Uberaba (Fig. 1). The drainage flows on the ancient lateritic land surface that corresponds to a well-preserved flat plateau shaped on sandstone with iron-rich silty and clay layers belonging to Marilia Formation (Upper Cretaceous) [22].

The wetland network developed on the flat plateau represents concavities periodically waterlogged. In the catchment, wetlands could be considered the zero-order basin (in the sense of Sidle [23]) because they show convergent contour lines between the depressions on hillslope and river channels without the development of the surface channel. In the field, the grassy vegetation, the presence of Plinthosol with low chroma $(<2)$, and high organic carbon accumulation in topsoil are the main characteristics to recognize wetlands and are used to distinguish that ecosystem from the surround open savanna (Cerrado).

In the catchment, the slopes are gentle $(<5 \%)$, the interfluves are wide and the valleys are flat-large without river incision. In the plateau, the soil cover is dominated by redyellowish Ferralsols [24] or Latossolo Vermelho-Amarelo [25] located in well-drained positions and Plinthosols [24] or Plintossolos [25] located in wetlands. In this study, the soil profiles analyzed in the catena correspond to Plinthosol developed from the border to the center of the wetland.

The seasonality of precipitation characterizes the Cerrado. The average annual rainfall is $1474 \mathrm{~mm}$ from 1975 to 2010 [26], and the rain volume is concentrated from November to March. The dynamics of wetlands follow the regime of precipitation becoming full of water during the 


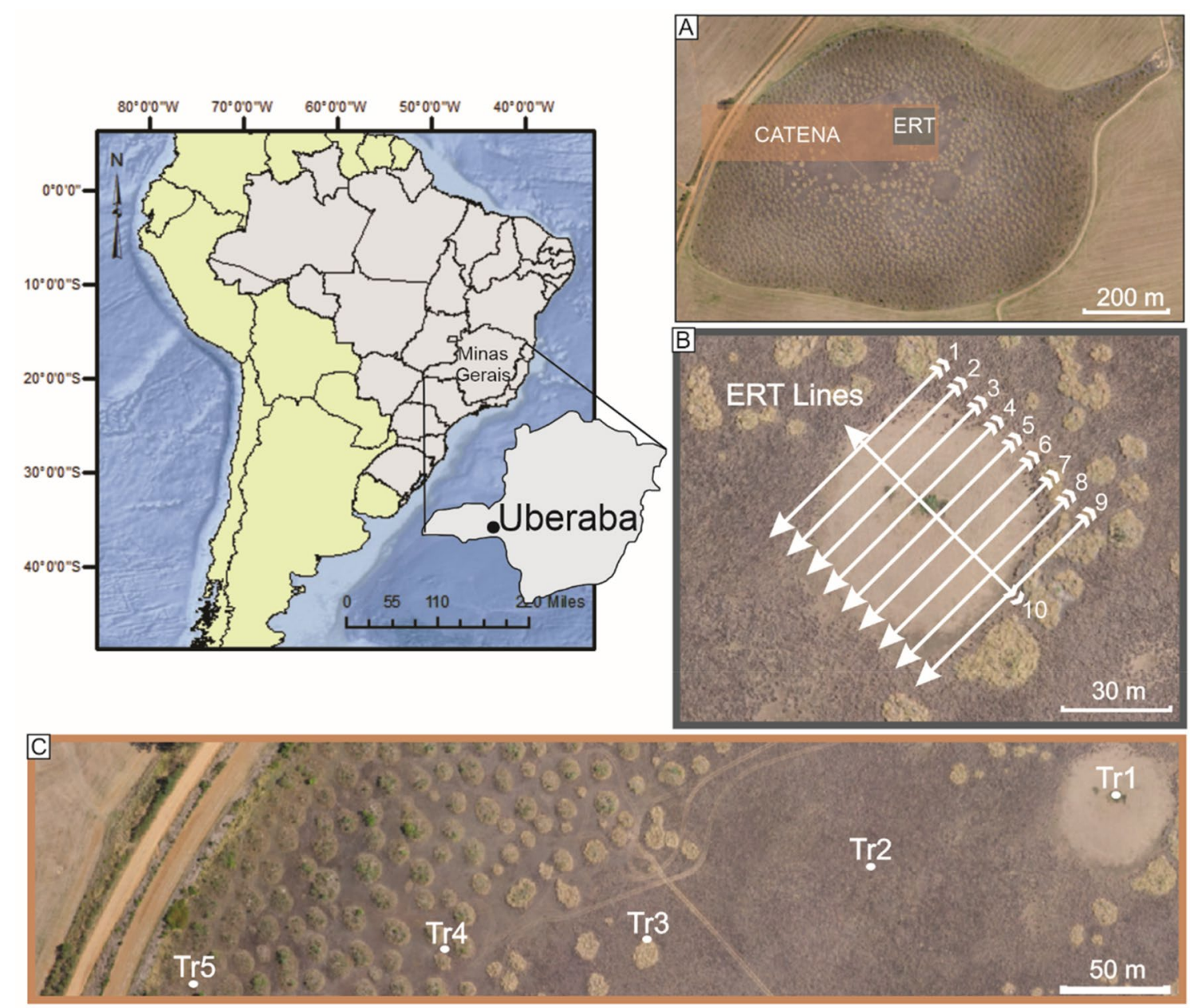

Fig. 1 Geographic location of the studied wetland with a zoom-in in the: a wetland with the disposition of the catena and electrical tomography (ERT) survey; b location and disposition of the ERT

wet season and lost water during the dry season. The average annual temperature is $23^{\circ} \mathrm{C}$ [26]. When flooded, in the center of the area the water reaches up $1.65 \mathrm{~m}$ from the land surface and $0.2 \mathrm{~m}$ in the border.

\subsection{Soil descriptions and sampling}

The soil was described and sampled in a catena. Five trenches (TR1 to TR5) (Fig. 1) were opened from the border to the center of the wetland and the limits among them were defined according to topography and visible changes in vegetation cover. The trench TR1 (965 $\mathrm{m}$ a.s.l.) was located in the center of the wetland on a poorly drained soil with creeping grass, TR2 (966 $\mathrm{m}$ a.s.l.) was located bordering this zone with tall perennial grasses, TR3 $(966.5 \mathrm{~m}$ a.s.l.) and TR4 (966.7 $\mathrm{m}$ a.s.l.) were dug inside the microtopographic belt covered by shrubs and small savanna trees with adjacent depressed areas which surround lines and $\mathbf{c}$ location of the catena profile and the position of each trench ( $\operatorname{Tr} 1$ to $\operatorname{Tr} 5)$. $\mathbf{a}$ and $\mathbf{b}$ are adapted from [57]

the center of the depression, and TR5 (967 m.a.s.l.) was located in the border between the well-drained plateau with Ferralsol and the wetland (topographic depression) with Plinthosol and covered by small trees and shrubs. The trenches depth varied according to the level of the water table. The water table was at $0.9 \mathrm{~m}, 1.0 \mathrm{~m}, 1.0 \mathrm{~m}, 1.0 \mathrm{~m}$, and $1.5 \mathrm{~m}$ from TR1 to TR5. The wetland has a soft slope $(<5 \%)$.

The soil morphological descriptions were made following IUSS 2015 and soil color with the Munsell Soil Color Charts [27]. The samples were collected within layers considering the most distinctive visual features, particularly soil color, structures, and textures. In each layer, it were collected three sub-samples and mixed them to obtain one composite sample representative of each layer. A total of 16 soil samples were placed in plastic bags, transported to the laboratory, and sieved with 2-mm mesh to remove coarse materials. The particle size distribution was made using the pipette method, following organic matter 
removal with $\mathrm{H}_{2} \mathrm{O}_{2}$ and dispersion with Na-hexametaphosphate [28]. Sand fractions ( $\varnothing>0.5 \mathrm{~mm}$ ) were obtained by wet sieving after dispersion, and clay $(\varnothing<0.002 \mathrm{~mm})$ and silt fractions by sedimentation, followed by siphoning and pipetting, respectively.

Undisturbed soil samples $(9 \times 5 \mathrm{~cm})$ were collected to micromorphological study. The samples were impregnated with polyester resin, cut into thin sections, and polished. Micromorphological descriptions were performed following Stoops et al. [29] using an optical microscope Zeiss Axioskop 40 integrated with a 5.0 megapixels Canon digital camera. Soil bulk density was measured using a metallic ring core method and expressed as $\mathrm{g} \mathrm{cm}^{-3}$ [30].

\subsection{Field test of soil hydraulic conductivity}

The determination of coefficient soil hydraulic conductivity in the field was made using a Guelph Permeameter [31]. The method was used to determine field saturated hydraulic conductivity (Ksat) in situ. Next to the trenches TR1, TR2, TR3, TR4, and TR5, after cleaned-up the soil surface, boreholes were excavated with a hand auger (auger cutting diameter of $6.0 \mathrm{~cm}$ ) to reach up every identified soil horizon. Measurements were carried out after the morphological soil description and choice of soil horizons based on soil structure, cohesion, mottling, and accumulation of organic matter.

When a constant water level (hydraulic load) is established inside the boring hole, a "bulb" of water saturation is created from its base. The volume of water infiltrating the soil per unit of time (rate of infiltration) becomes constant after a certain time of stabilization. The characteristics and dimensions of this water saturation "bulb," once reached the condition of stability, vary with the characteristics of the soil tested.

The value of the infiltration rate, associated to the hole dimensions and the variation of the height of the water column inside ( $H 1$ and $H 2)$, allows the calculation of hydraulic conductivity in situ, using the following expression, according to Soil Moisture Corporation [32]:

$K=[(0,0041)(X)(R 2)-(0,0054)(X)(R 1)]$

or

$K=[(0,0041)(Y)(R 2)-(0,0054)(Y)(R 1)]$

where $K$ is hydraulic conductivity, in $\mathrm{cm} \mathrm{s}^{-1} ; R 1 ; R 2$-stabilized infiltration rates corresponding to $H 1$ and $H 2$, respectively, in $\mathrm{cm} \mathrm{s}^{-1} ; X ; Y$-constants corresponding to the area of the tube (water reservoir) used, in $\mathrm{cm}^{2}$ and 0.0041 and 0.0054 -dimensionless values.

In the hydraulic conductivity tests with the Guelph Permeameter both reservoirs, internal and external, were used. As a consequence, the constant used in the calculations was $X=35.46 \mathrm{~cm}^{2}$, for saturated soils.

\subsection{Surface water accumulation}

Very-high-resolution (VHR) digital elevation models (DEM) obtained through UAV photogrammetry are among the most important spatial information tools to investigate geomorphology and hydrology [33]. In order to reveal VHR topographic data, we used the eBeePlus RTK/PPK fixed-wing UAV with an optical red-green-blue Sensor Optimised for Drone Applications, 20 megapixels (sensefly.com).

The data were processed in the following software and steps: (1) Emotion Software 3.0, by SenseFly, to plan the cross-flight with $70 \%$ lateral and longitudinal overlap, resulting in a better resolution of the DEM for the relief analysis [34]; (2) Planialtimetric correction using the GNSS Topcon Hiper PRO RTK with data acquisition during the flyovers, resulting in a precision of $0.038 \mathrm{~m}$ (Post-Processed Kinematic) against $6.220 \mathrm{~m}$ (Real-Time Kinematic), with the onboard GPS; (3) Agisoft Metashape (agisoft.com) software to perform the digital photogrammetry, generating the orthomosaic and the VHR DEM to the relief and water accumulation analysis; and (4) gis-platform software to extract the red-green-blue bands from the orthomosaic and combine then in different levels (draw raster as an RGB composition), to differentiate vegetation of different kinds and regions of water accumulation inside the wetland.

\subsection{Soil infiltration architecture and subsurface water-flow}

The infiltration architecture is directly related to the heterogeneity of the soil-water interface and the application of geophysical techniques contributes to access the subsurface complexity. Two-dimensional electrical tomography and three-dimensional models of resistivity $(\Omega \mathrm{m})(\Omega$ $\mathrm{m}$ ) can be used to investigate the subsurface structures of the soil, bedrock, saprolite, and to generate an estimation of the flow and accumulation of groundwater.

To measure the geo-electrical properties, the Terrameter LS equipment (Guideline Geo Instrument, Sweden) was used with the transmission of $200 \mathrm{~mA}$ for $1 \mathrm{~s}$ for each measurement. Iron electrodes were distributed every $2 \mathrm{~m}$ in nine lines $80 \mathrm{~m}$ long and one line $(80 \mathrm{~m})$ perpendicular to all. The spacing between the lines was established at $10 \mathrm{~m}$, and the array configured for data acquisition was the Wenner-Schlumberger (Fig. 1).

The data were processed in the following software: (1) Res2Dinv (geotomosoft.com), to generate 2D inversion models for DC Resistivity using the algorithm of smoothness constrained least-squares method that uses the 
optimization Gauss-Newton and quasi-Newton [35, 36] and to perform topographic modeling when reversing the data set (Geotomo Software 2003) with the topographic data acquired by GNSS in the field. Depending on the line processed, a minimum of 4 and a maximum of 7 interactions were performed, but all of them with 12 levels of depth; and (2) Oasis Montaj platform (geosoft.com), to process the pseudo-3D model based in the 2D data interpolated using the minimum curvature method.

\section{Results and discussion}

\subsection{Soil morphology, soil texture, and bulk density related to hydrodynamics of wetlands}

The soil morphology and physical properties are shown in Table 1 and in Fig. 2. The TR5 profile located at the border of the wetland has three horizons and represents the better water-drained sequence. The topsoil is dark reddish-yellow and granular. Underlying, the horizon is massive, light gray, with fine red mottles overlaying a deeper massive mottled horizon with hard ferruginous nodules. Toward downslope, the next profile TR4 has three horizons. The topsoil is dark yellowish-brown with a weak

Table 1 Descriptive and physical analysis information for each soil horizon identified in each of the trenches

\begin{tabular}{|c|c|c|c|c|c|c|c|}
\hline \multirow[t]{2}{*}{ Trench* } & \multirow{2}{*}{$\begin{array}{l}\text { Horizon } \\
\text { depth } \\
(\mathrm{cm})\end{array}$} & \multirow[t]{2}{*}{ Description } & \multicolumn{3}{|c|}{$\begin{array}{l}\text { Grain size analysis } \\
\left(\mathrm{g} \mathrm{kg}^{-1}\right)\end{array}$} & \multirow{2}{*}{$\begin{array}{l}\text { Bulk } \\
\text { density (g } \\
\left.\mathrm{cm}^{3}\right)\end{array}$} & \multirow{2}{*}{$\begin{array}{l}\text { Hydraulic } \\
\text { conductivity } \\
\left(\mathrm{cm} \mathrm{s}^{-1}\right)\end{array}$} \\
\hline & & & Sand & Silty & Clay & & \\
\hline \multirow[t]{4}{*}{ TR1 } & $0-30$ & $\begin{array}{l}\text { Black with few medium faint spots dark grayish brown (10YR 4/2); clay; } \\
\text { very fine roots of grass; massive with weak granular structure; vertical } \\
\text { cracks; gradual boundary }\end{array}$ & 273 & 152 & 575 & 0.51 & $8.6 \times 10^{-3}$ \\
\hline & $30-53$ & $\begin{array}{l}\text { Gray with dark gray material derived from surface horizon; clay with } \\
\text { some cleaned sand grains; vertical cracks filled with black organic } \\
\text { matter; abrupt boundary }\end{array}$ & 256 & 160 & 584 & 1.3 & - \\
\hline & $53-65$ & $\begin{array}{l}\text { Light gray; clay with increase in sand fraction; massive; platy hard fer- } \\
\text { ruginous concentration; clear and irregular boundary }\end{array}$ & 256 & 156 & 588 & 1.3 & $5.6 \times 10^{-3}$ \\
\hline & $65-100$ & $\begin{array}{l}\text { Yellow red with common mottles yellow and gray; } 5 \% \text { of hard ferrugi- } \\
\text { nous nodules }(\mathrm{mm}) \text {; clay, massive }\end{array}$ & 190 & 171 & 639 & 1.0 & $1.4 \times 10^{-4}$ \\
\hline \multirow[t]{3}{*}{ TR2 } & $0-25$ & $\begin{array}{l}\text { Black; weak granular; clay; vertical cracks with decomposed roots and } \\
\text { yellow iron impregnation; gradual boundary }\end{array}$ & 223 & 162 & 615 & 0.60 & $6.4 \times 10^{-3}$ \\
\hline & $25-73$ & $\begin{array}{l}\text { Light gray with fine red and yellowish-red mottles; rare ferruginous } \\
\text { nodules; clay; massive; gradual boundary }\end{array}$ & 140 & 172 & 678 & 1.0 & - \\
\hline & $73-100$ & $\begin{array}{l}\text { Mottled light gray and red; clay; hard ferruginous nodules ( } \mathrm{mm}) \text {; mas- } \\
\text { sive }\end{array}$ & 156 & 175 & 669 & 0.60 & $3.0 \times 10^{-5}$ \\
\hline \multirow[t]{3}{*}{ TR3 } & $0-9$ & Dark grey; clay; fine granular; diffuse boundary & 156 & 175 & 669 & 0.60 & $3.1 \times 10^{-4}$ \\
\hline & $9-55$ & $\begin{array}{l}\text { Light grey with very few mottles yellow and red; clayey; massive with } \\
\text { small granular substructure; diffuse boundary }\end{array}$ & 173 & 171 & 656 & 1.0 & $1.6 \times 10^{-4}$ \\
\hline & $55-92$ & $\begin{array}{l}\text { Light grey with small mottles yellow and red; clayey; massive with small } \\
\text { granular substructure }\end{array}$ & 190 & 175 & 635 & 1.0 & - \\
\hline \multirow[t]{3}{*}{ TR4 } & $0-14$ & Dark yellowish brown; weak granular; clay; clear boundary & 290 & 156 & 554 & 0.63 & $5.2 \times 10^{-4}$ \\
\hline & $14-61$ & $\begin{array}{l}\text { Light grey with fine mottles light reddish brown; clay; massive; vertical } \\
\text { cracks filled with organic matter; diffuse boundary }\end{array}$ & 256 & 160 & 584 & 1.0 & $2.0 \times 10^{-5}$ \\
\hline & $61-100$ & $\begin{array}{l}\text { Pale yellow with mottles light reddish brown; hard ferruginous nodules } \\
(\mathrm{mm}) \text {; clay; massive }\end{array}$ & 223 & 162 & 615 & 1.0 & - \\
\hline \multirow[t]{3}{*}{ TR5 } & $0-21$ & $\begin{array}{l}\text { Dark reddish yellow; granular; clay; decomposed roots with impregna- } \\
\text { tion of iron; gradual boundary }\end{array}$ & 256 & 156 & 588 & 0.65 & $1.0 \times 10^{-3}$ \\
\hline & 21-98 & $\begin{array}{l}\text { Light gray with fine mottles red; ferruginous nodules (mm); clay; mas- } \\
\text { sive; diffuse transition }\end{array}$ & 190 & 171 & 639 & 1.4 & - \\
\hline & $98-150$ & $\begin{array}{l}\text { Pale yellow with fine mottles light reddish brown; hard ferruginous nod- } \\
\text { ules (mm); massive; clay }\end{array}$ & 190 & 175 & 635 & 1.3 & - \\
\hline
\end{tabular}

Description according IUSS 2015

*Profiles photos are shown in Fig. 2 

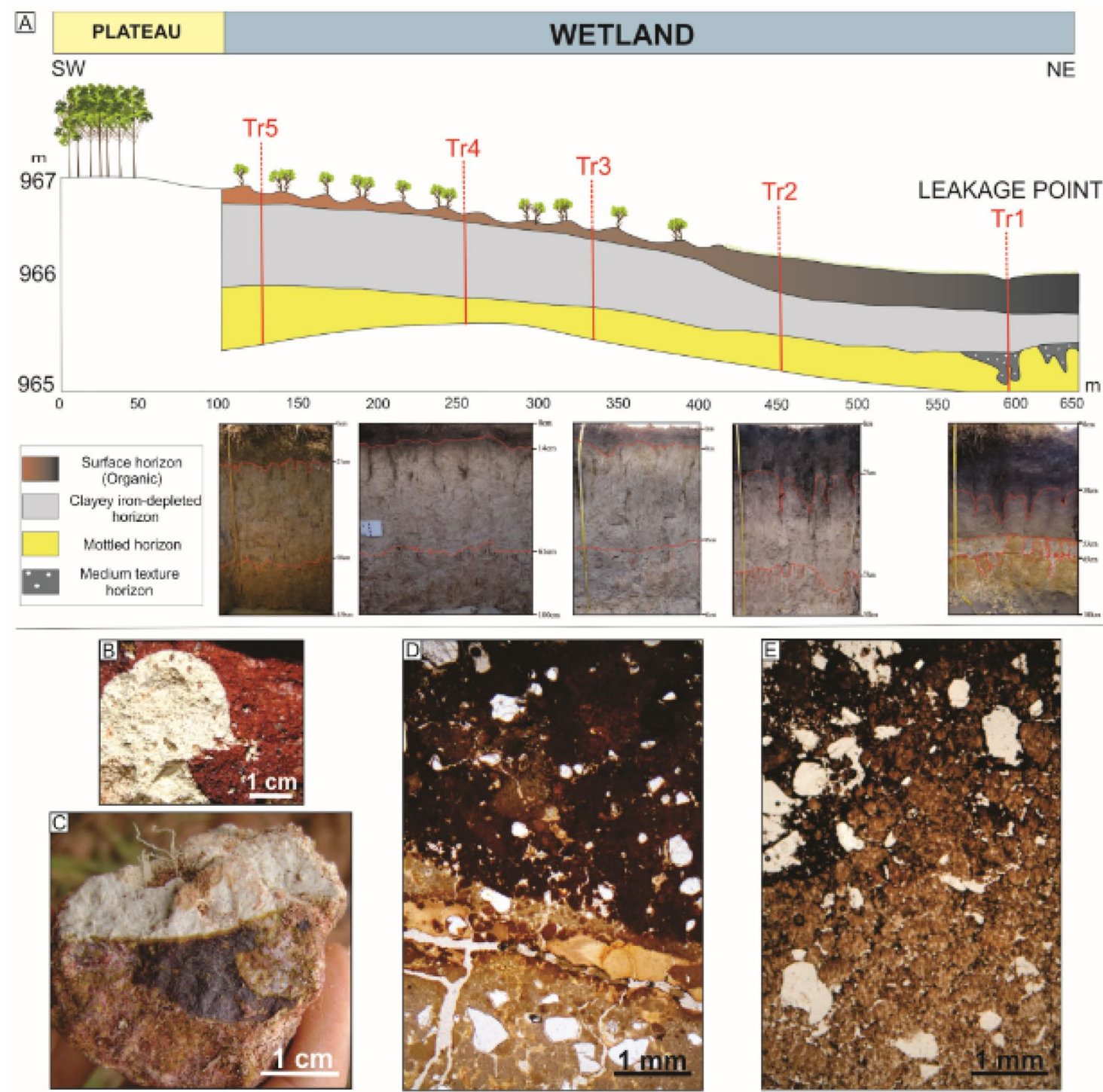

Fig. 2 a Plinthosol profile with SW-NE direction in the studied wetland, with the images of all the studied soil profiles and its position on the wetland; $\mathbf{b}$ and $\mathbf{c}$ Field samples associating the deferrugination and collapse of pre-existing soil matrix; d Ferruginized

granular structure. Above, the massive horizon is light grey with fine reddish-brown mottles. Vertical cracks filled with organic matter derived from topsoil cut this horizon. The deeper horizon is mottled with hard ferruginous nodules. The profile TR3 has fine granular dark grey topsoil. Above, the horizon is massive with granular substructure showing light grey with very few mottles yellow. The deeper horizon is massive with small granular substructure light grey with small mottles yellow and red.

The subsequent profiles TR2 and TR1 are representative of the center of wetland. In TR2 the topsoil is black, weak granular with vertical cracks presenting decomposed roots and iron concentration in the wall. Underlying, occur (red) and deferruginized (gray) soil matrices linked to the increase in water in soil profile. Presence de hipocutans (yellow) in the pores and clay particles mechanically transported (elluviated clay); e compacted iron-depleted structure in hydromorphic condition

a massive and light gray with fine red and yellowish-red mottles and, below it, a horizon mottled light gray and red with hard ferruginous nodules. Finally, the topsoil of the profile TR1 is black that overlaps a light gray horizon with dark gray organic material from the surface. Some cleaned sand grains are embedded in the clay matrix. Vertical cracks are filled with black organic matter. In the irregular boundary between the light gray and the underlying mottled yellow-red-gray horizon occurs a thin platy hard ferruginous concentration. Hard ferruginous nodules are spread in the mottled horizon.

Soil horizons exhibit overall redoximorphic features and organic matter accumulation typical of hydric conditions 
[37]. Mottled and iron-depleted matrices with low chroma $(<2)$ are typical of water saturation and anaerobic conditions both related to wetland topography and hydrology. In the catena, the horizons with the dominance of light gray matrices increase toward the center of the topographic depression and are systematically located below the topsoil and above the red-yellow-gray mottled horizons indicating features produced by a long duration of soil-water saturation [13]. Soil morphology is a qualitative attribute useful to evaluate soil wetness and the temporal variation in soil water content, either due to a seasonal high groundwater level or to a slowly permeable layer in the subsoil which causes periods of saturation $[38,39]$.

Lower bulk density was found in surface horizons (Organic) associated with high soil organic matter and with well-developed pedality. Considering this horizon in all profiles, the densities range from $0.51 \mathrm{~g} \mathrm{~cm}^{-3}$ (TR1) to $0.65 \mathrm{~g} \mathrm{~cm}^{-3}$ (TR5).

The development of a gray horizon implies in the increase in bulk density ranging from 1.0 to $1.4 \mathrm{~g} \mathrm{~cm}^{-3}$. The increase in bulk density in that soils is due to the collapse of soil aggregates linked to the disruption between iron-clay in aquic conditions [40]. Under higher bulk density in compacted level, infiltration rates are significantly reduced decreasing the efficiency of rainfall contribution to the groundwater [41]. The iron-depleted and compacted horizons constitute a continuous level developed from the border to the center of wetland which works as a barrier to the rainwater vertical flow (Fig. 2e).

The Ksat values obtained on soil profiles clearly change according to soil horizons (Table 1). In this study, the reference values of low-to-medium hydraulic conductivity vary on the scale of $10^{-3}$ and $10^{-4} \mathrm{~cm} \mathrm{~s}^{-1}$, at depths of 10 to $56 \mathrm{~cm}$. Some horizons do not have measures of hydraulic conductivity, this is due to a limitation of the equipment itself (Guelph Permeameter), which depending on saturation, soil capillarity and compaction it is not possible to carry out valid in situ measures.

Comparing the profiles of soil catena, TR1 has the highest values of Ksat $\left(8.6 \times 10^{-3}\right)$. In TR2, TR3, and TR4 the majority of the measured values are on the scale of $10^{-4}$ and $10^{-5} \mathrm{~cm} \mathrm{~s}^{-1}$, classified from low to very low $[42,43]$.

Similarly, the clayey soil texture contributes to amplify the hydromorphy. Clay content values exhibited low oscillation in the profiles excepted by a slight increase in sand occurs at $48-56 \mathrm{~cm}$ in TR1 (Table 1). In fine-textured soils, the water fills all pores preventing the entrance of oxygen, increasing Fe releasing and redox depletions [13] (Fig. 2b-d). The dominance of clayey texture in the studied wetland resulted from geological and pedological processes. The sedimentary rock of Serra da Galga Member (Marilia Formation) is composed by clayey layers enriched with diagenetic kaolinite interbedded by sandy to sand-clay materials roughly parallel to the land surface [22]. Since the Upper-Cretaceous, the clayey sandstone was deeply weathered and up to now the active tropical pedogenesis on the plateau has originating soils enriched in kaolinite, gibbsite, hematite and goethite.

In the area, the soil wetness is conditioned by both, the seasonality of climate and soil properties which restrict the rainwater infiltration. In the Brazilian Cerrado, both vegetation type and tillage practices control soil water content and seepage to groundwater [44]. In the core of Cerrado, specifically in the wood savanna located in Águas Emendadas (an experimental area located near Brasília-DF), the estimated evapotranspiration (ETa) varied between 2.48 and $6.56 \mathrm{~mm}$ day $^{-1}$ (an average value of $2.81 \mathrm{~mm} \mathrm{day}^{-1}$ for the wet season and $1.70 \mathrm{~mm}$ day $^{-1}$ for the dry season) and the lowest $\mathrm{ETa}<1.00 \mathrm{~mm}_{\text {day }^{-1}}$ occurs when the soil moisture decreases $[45,46]$. According to Oliveira et al. [46], the increase in grass cover (campo sujo) reduces ETa from 0 to $9 \mathrm{~mm} \mathrm{day}^{-1}$ in the dry season to $4.5 \mathrm{~mm}$ day $^{-1}$ in the early wet season. The spatial distribution of ETa in the Cerrado is dependent on water availability in the soil and by phenological stage, canopy, geometry, and structure/ depth of the root system vegetation [46]. Albeit ETa is a large-range hydro-meteorological variable, the estimated annual mean of ETa in a tropical wetland (East Africa) was $1286 \mathrm{~mm}$, higher than the determined in other landcover classes because this parameter is mostly controlled by water availability [47]. This behavior suggests that in the studied catchment wetlands are a special environment with a fundamental role in the hydrological cycle in the plateau, storing rainwater, feed aquifer, and releasing water for the atmosphere.

The rainwater flows faster through topsoil (a set of horizons with higher Ksat values) because grass roots, well developed pedality and higher SOC contents. On the iron-depleted subsurface horizons (with lower Ksat) vertical water flows is slower. Previous studies (i.e., [48]) show strong relationships between Ksat and soil attributes as texture, structure and bulk density and soil organic carbon. The distinct Ksat between surface and subsurface horizons is important to keep rainwater on the ground surface longer. The rainwater that falls between October to March and is partially retained correspond to the major processes for the wetland flooding. Near the surface, soil moisture fluctuations are very frequent and moisture spikes immediately follow rainfall events. The higher concentration of roots and well-developed soil structure result in more intense absorption of rainwater. In addition, the gravitational component quickly drains this water vertically. The dense subsoil stops drainage and sustains the periodic saturation in the wetland. Simulating the water infiltration pattern through Ksat values, the low permeable 
layer in subsurface originates perched groundwater and influences over the soil hydraulic behavior [49].

Under saturated soil conditions, the preferential direction of water-flow is lateral, from upslope to downslope [6]. However, occurs an exception in the center of the wetland (profile TR1) where the hydraulic conductivity is higher in the deepest horizons-possibly related to a gentle increase in sand materials. Although does not always exist a direct relationship between soil texture and Ksat, the increase in sandy-clay fraction in subsurface can also increases hydraulic conductivity in soil profiles [50]. This profile can be considered a water leak point on wetlands which enable the vertical water flow reaching the aquifer.

An important condition that influences hydraulic conductivity values is soil heterogeneity, which can be related to different particle sizes, densities, compaction, denudation, macroporosity, land use, and ecosystem dynamics [51]. In practice, tests performed in relatively close locations showed results with differences of up to 10 or 100 times, although overall the results are low and approximate. Due to soil heterogeneity, hydraulic conductivity is an extremely difficult variable to be spatially distributed. Because the wetland is located on a flat plateau and it is not connected to the river through a superficial channel, the preferential lateral water flow in soil and groundwater occurs [14] — which corroborates the low rates of hydraulic conductivity measured on the surface of the studied area.

Both, soil texture and bulk density deep influence soil-water storage and soil hydraulic properties and are responsible for nearly $50 \%$ of the temporal stability in the watershed $[52,53]$.

The soil physical properties in wetland were acquired by soil change processes that operate to modify existing lateritic soil (processes of soil change in the sense of Fanning and Fanning [54]). The restrictive zone to water permeability in subsurface layers is a consequence of the decrease in pedality due to hydromorphy. The high soil heterogeneity, both inside and around the wetland, alter the previous soil-water content and soil-water storage pattern at hillslope scale [55]. Soil layering and hydrology are interchangeable processes and their complexity represents disruptions generated by landscape evolution [56].

\subsection{The depressional wetland's landscape and infiltration architecture}

Combining UAV image processing, geophysical techniques, and soil properties, it was possible to access the water-flow from hydric soil to aquifer. The infiltration architecture (subsurface heterogeneity) can be unveiled in ERT $2 \mathrm{D}$ and pseudo-3D imaging. It is important to understand the infiltration architecture because the organization of the subsoil is directly related to the genesis and water dynamics of the wetlands.

The images provided details of soil architecture and saprolite affecting hydrologic processes across the wetland, which is located in the middle of the flat plateau and is not superficially connected with river channels. The studied wetland has an area of $426.064 \mathrm{~m}^{2}$ and stores $416.996 \mathrm{~m}^{3}$ of rainwater precipitated over the summer months (1474 mm from October to March) [57]. The external hydric soils limit vary during the year, expanding the flooded area during the summer and contracting during the dry months. Due to the non-existence of superficial connection with the river, the functionality between soil-water and aquifer in the geographically isolated wetlands is influenced by the structure of hydric soils and internal topography, both determining the lateral and subsurface flows, controlling downstream flow and acting as discharge and recharge areas [58].

Figure 3 shows the internal pattern of the studied wetland: (1) shrub and tall grass vegetation that dominate in the border of wetland and (2) short-grass vegetation organized in circular patches located exclusively in the
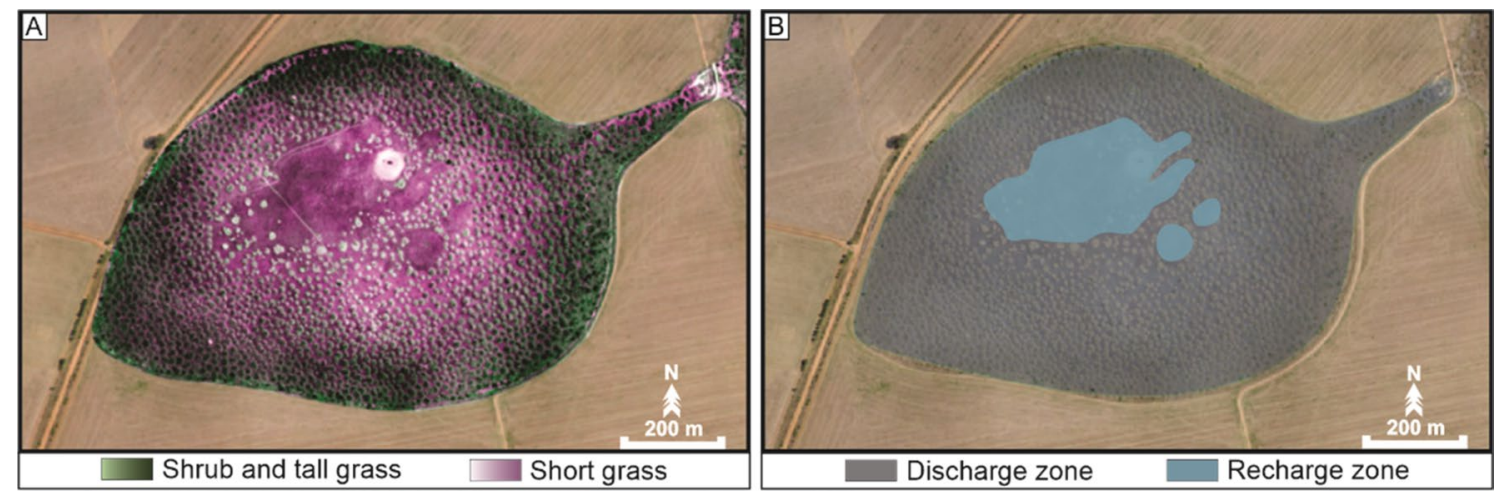

Fig. 3 Polygons extracted from UAV images (bands combination) representing the delineation units of the general vegetation and hydrological zones inside-pattern of the studied wetland. $\mathbf{a}$ Vegetation pattern inside the wetland and $\mathbf{b}$ recharge and discharge zones 
center of wetland in the largest topographical sinking. Each pattern represents hydrologic soils influenced by distinct microtopography, vegetation, and local distribution of water [59-61]. In the Cerrado biome, vegetation structure is strongly related to groundwater depth [19].

The analysis of the zones of different geo-electrical resistivity's can indicate both, the presence of groundwater (high resistivity values) and dry soil (low resistivity)
[62-64]. In the studied wetland, low values of resistivity ranged from 200 to $612(\Omega \mathrm{m})$ (blue colors) and high values of resistivity from 1870 to $10,000(\Omega \mathrm{m})$ (dark green, brown and red colors) (Fig. 4). In Fig. 4, we can observe the saturated and unsaturated zones, originating from the leakage point.

The pattern of land surface combined with ERT images were used to make broader hydrologic interpretation of
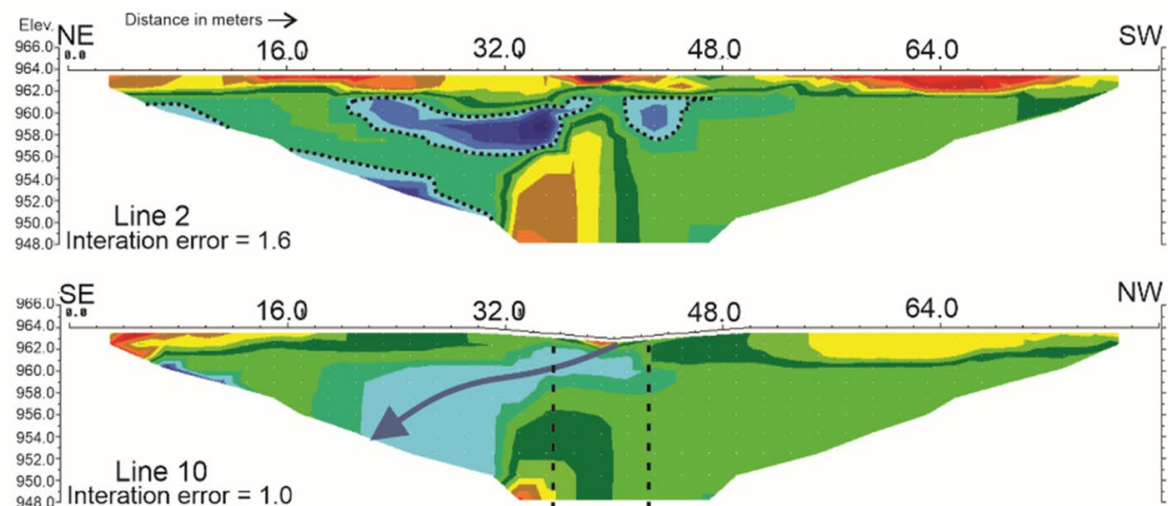

948.0 Interation error $=1.0$

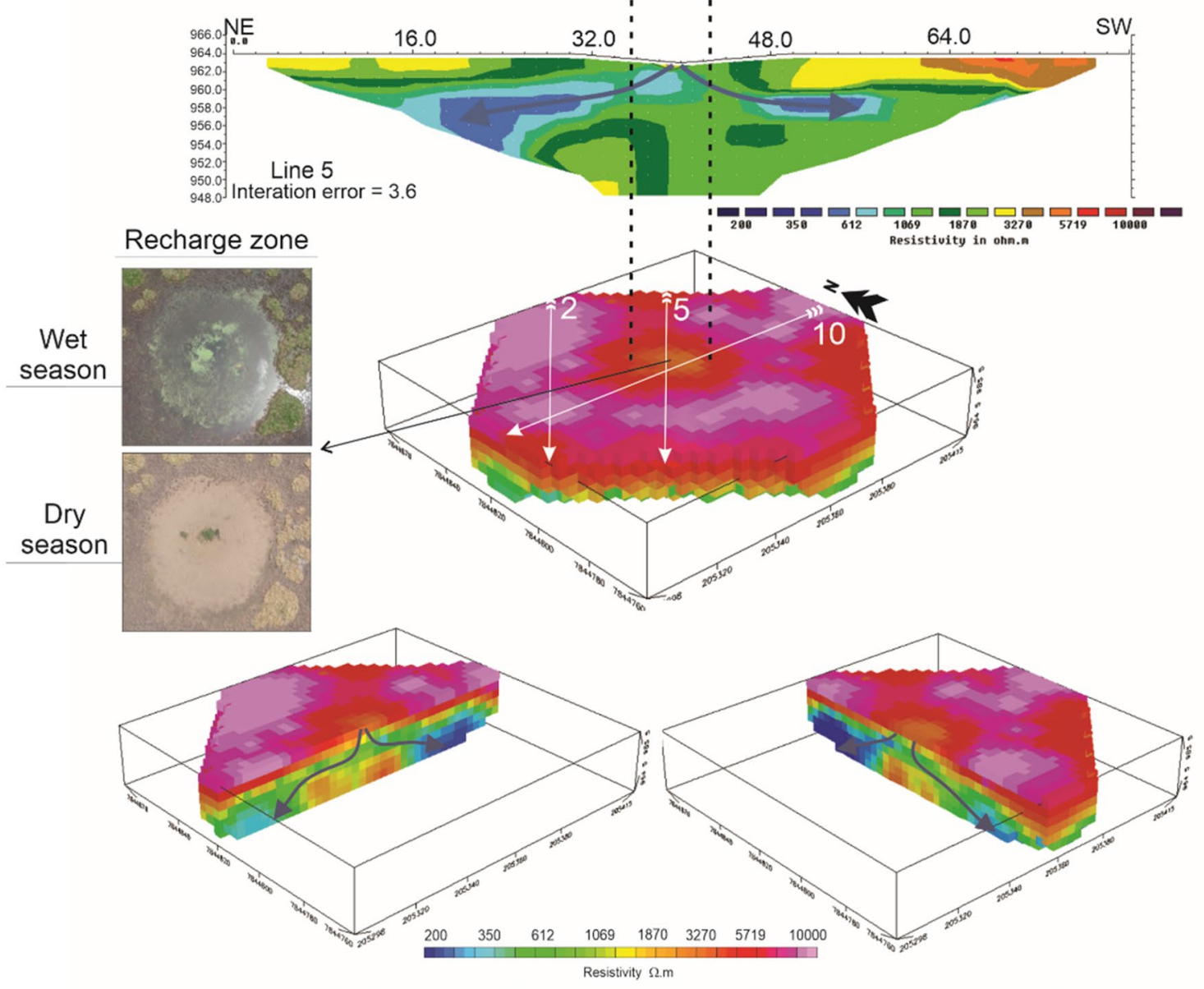

$2.0 \quad 48.0 \quad 64.0 \quad$ SW

Fig. 4. 2D profiles (lines 2, 5, 10) (adapted from [57]) and Pseudo-3D ERT images acquired in the center of the studied wetland, where it is observed a leakage point, i.e., the recharge zone (shown in the wet and dry seasons UAV images) 
wetland landscape (Fig. 3): (1) recharge zone characterized by direct vertical water flow from soil to groundwater and (2) discharge zone characterized by lateral water subsurface-flow until a stream.

The 2D profiles were previously studied by Furlan et al. [57], which quantified the amount of water stored in this landscape and indicated the complexity and heterogeneity of the soil as responsible for the wetland's hydrodynamic. The superficial center of the 5 and $102 \mathrm{D}$ profiles (Fig. 4), where there is the leakage point, is the locality of lowest resistivity in the center of the wetland associated with the lowest topography and higher hydraulic conductivity (recharge zone). These properties may be related to the fact that soils in isolated depressions and in the recharge zone are dominated by leaching and redox depletion, both active processes of chemical erosion [13]. Terrain variables are closely related to soil moisture patterns and dynamics, both important in defining soil hydrological function [65]. In the recharge zone, the rainwater stored in the wetland infiltrates deep into soils connecting to the aquifer through vertical flow [57].

The discharge zone is characterized by preferential lateral water flows in soil and groundwater controlled by a decreased hydraulic conductivity in layers of soil and saprolite. The profile 2 is representative of all other profiles, with the surface layers showing high resistivity, which can be associated with lower hydraulic conductivity. However, at greater depths, it is possible to observe the continuity of the groundwater. The fine soil texture occurring there can also retain water and shows lower resistivity [66]. In the soil mantle and saprolite, layers of increased saturation lead to more lateral hydraulic conductivity [67] and the dense and fine-textured layers in the bedrock and soil mantle retain the water-flow [68].

The iron-depleted and compacted subsurface layers in wetland soil profiles and the heterogeneity in the finestructured saprolite reduce the permeability at depth causing a subsequent lateral flow fundamental component of stream flow discharge [69]. According to the authors, the lateral subsurface flow is triggered often by a perched water table within the soil or the soil bedrock interface converted to saturated zone, the most common mechanism for delivery of water from slopes into the valley bottom.

Bidirectional water-flow in the wetland plays an important role in the hydrological processes on the catchment of plateau since it represents a landscape where rainwater is stored, exchanged with the aquifer and the river. The contemporary flow path has been guided by the soil change process and the formation of topographic depression (isolated wetland) embedded in ferruginous upland soils is attributed to the iron-depletion compaction of pre-existing ferricrete. The released iron from the soil due to the excess of water opened a preferential path for water infiltration reaching the aquifer causing a connection between soil-water (surface water) and aquifer (groundwater). The process was facilitated because isolated wetland typically develops at locations where the shallow water table reaches the land surface [70].

In the studied wetland occurs a synergy between the soil process and hydrodynamics. The self-organization of the soil system that determines the hydrological behavior of the catchments is related to the development of modern drainage network on the residual plateau triggered by soil iron-depleted which corresponds to an evolutionary stage of the lateritic landscape, possibly marked by climatic changes in the Quaternary $[40,71]$. The excess of water on the flat plateau, a remnant of South Americana Surface, is a result of the general rise of the water table due to the increase in climatic humidity in the Cerrado biome from 4.600 years Ma BP (Pliocene) to a present-day [72]. Palynological records from central Brazil showed that wet soil vegetations of wetlands (palm swamp or veredas) reach the present values after 7.000 year BP and from 5.600 year BP the climate was similar to that of the present day and as well the types of vegetation grew on top of the plateau: arboreal Cerrado, gallery forest, and palm swamp [73]. The heterogeneity in the species cover, richness, and diversity of endemic vegetation in the wetlands of Cerrado (in nine palm swamps investigated was found a total of 331 species, 167 genera, and 58 families and in all the sites had exclusive species) indicating that these environments are paths isolated from each other by the typical vegetation of Cerrado on dry soils [74]. The hydromorphic causes the collapse of soil structure and reduces the hydraulic conductivity creating an environment that sustains a suspended aquifer that reaches the maximum lateral expansion during the rainfall season. Since the rain stops in the dry season, the suspended aquifer retreats controlled by vertical flow in the center of the topographic depression toward the aquifer.

It is possible to observe that the saturated soil extends in-depth, after the leakage point in the superficial impermeable zone, conditioning the vertical flow and deflecting the water-flow to in direction northeast and southwest of the subsurface-wetland, to the rivers [57]. By overcoming the impermeable layers and reaching the saturated zone, this flow (deep aquifer) feeds springs in the lowermost topographies. Because wetlands are widely distributed on the plateau, they constitute a headwater influencing significantly the quantity and quality of water within adjacent streams [75]. 


\subsection{Wetland environmental sensitivity identified by UAV and ERT imagery}

In original conditions, the Cerrado covered an area of approximately $2,036,448 \mathrm{~km}^{2}$, which represents $23.92 \%$ of the Brazilian territory. However, in 2011, the deforested area reached $956,654 \mathrm{~km}^{2}$ [76], equivalent to almost $47 \%$ of the original Cerrado-cover territory. During 2019, 6,500 $\mathrm{km}^{2}$ of the Cerrado were deforested, of which $500 \mathrm{~km}$ (approximately $7.7 \%$ of the deforestation) were in the state of Minas Gerais [77].

Murundus-wetlands widely spread in the Cerrado are segments of the landscape whose dynamics is controlled by hydromorphic soil processes and are fragile and ecological complexity [38]. The area is rich in biodiversity having endemic fauna and flora, have a "sponge effect," buffering the impact of rainfall and water flows on the soil and store soil carbon and also filter residues of fertilizers and pesticides used in agriculture [78, 79].

Relating the ecological function of the isolated wetlands in the Cerrado with the intensive agriculture in the adjacent lands, UAV and ERT techniques can support the temporal analysis of the evolution of these ecosystems. Figure 5 shows UAV-RGB imaging at two different times. At first, the isolated wetland during a drought month (August) and the second during a rainy month (December). During the rainy months, the wetland stocks water
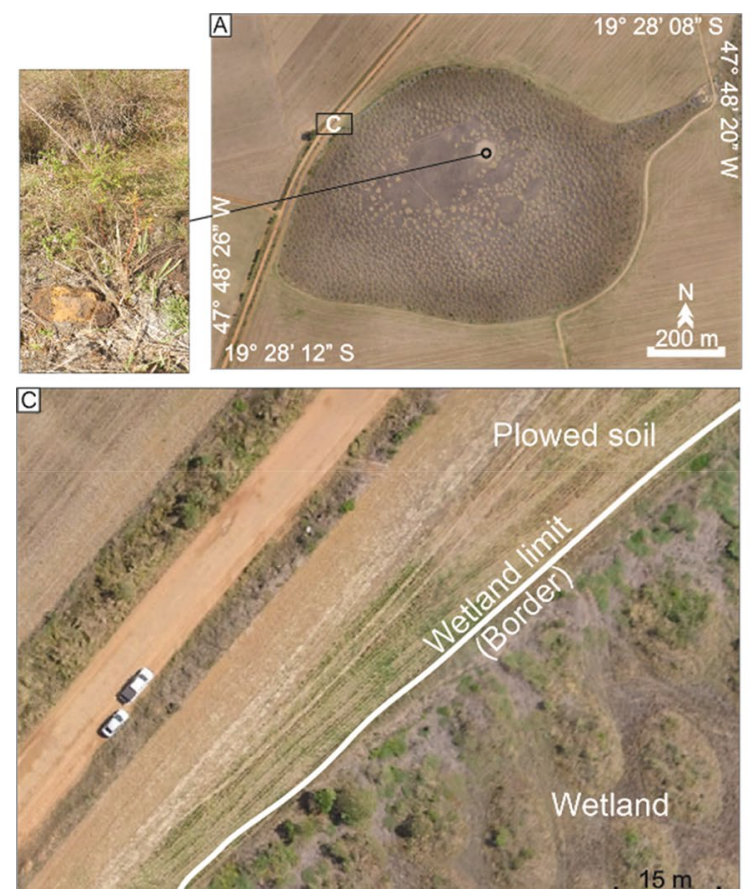

Fig. 5 UAV imaging at two different moments, with a zoom-in the vegetation a the isolated wetland during a drought month (August 2018), with short grass vegetation and $\mathbf{b}$ during a rainy month and, consequently, is habitat of a greater amount of fauna and flora. In this sense, the ecosystem sustained by the wetland follows its seasonal evolution.

In Fig. 5b, d, we observe that the areas adjacent to the wetland are also greenish, indicating the presence of greater vegetation in contrast to Fig. $5 \mathrm{a}$, c. These areas have historically been used for intensive agriculture (e.g., soybean crop). The first months of cultivation, the ones that most need chemical crop management are also the months when it has the highest rainfall rates. Also, there is no distance between the soybean crop and the wetland border (riparian forest), the wetland is literally surrounded by plowed soil or crops (Fig. 5c, d). This land-use dynamic can affect the supply of these chemicals to depressed or with a lower topography zones. Until now is uncertain if wetlands are being contaminated by agrochemical compounds because the data are punctual and do not represent the totality of humid areas. For example, Moraes and Horn [80] and Rosolen et al. [81] have found high contents of $\mathrm{As}, \mathrm{Cd}, \mathrm{Cr}$, Cu in five wetlands in the plateau, exceeding the threshold values established by Brazilian guidelines. At the same time, Ribeiro et al. [82] did not determine soil trace elements in sufficient quantities to characterize pollution or contamination.

The Digital Elevation Model (DEM) is useful for representing the continuously varying topographic surface of the relief, and it is a common data source for terrain
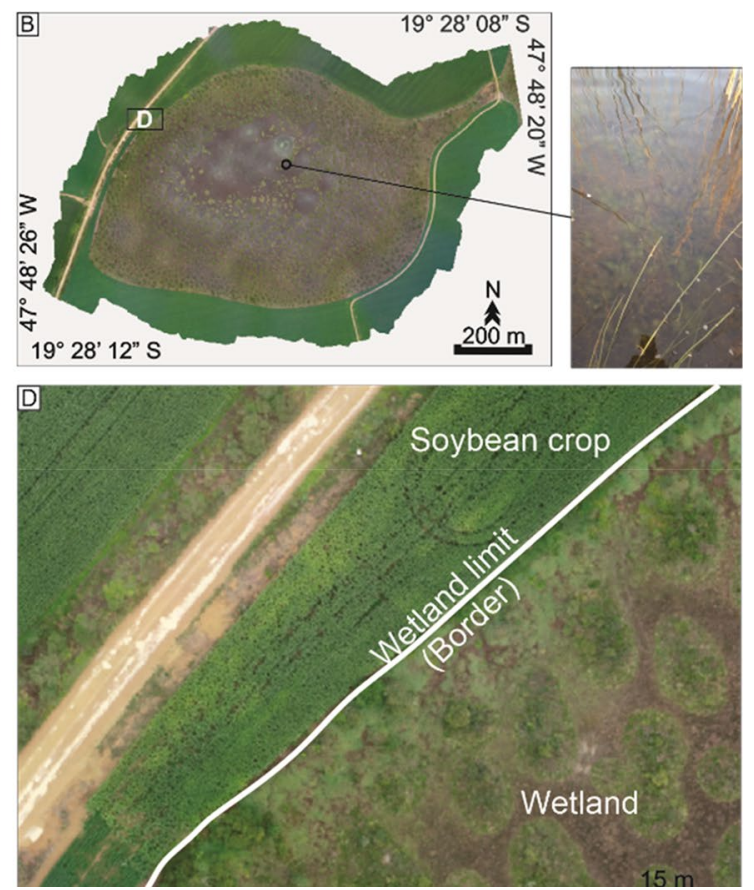

(December 2018), with submerged aquatic vegetation. c Dry season zoom-in the border and $\mathbf{d}$ wet season zoom-in the border 
analysis and other spatial applications [75]. This means that the DEM is a tool that helps to understand the surface water dynamics since the surface water flow is defined mainly by the morphology of the terrain and by the elements that constitute the landscape. In the locality, the isolated wetland represents a topographic depressed position, and therefore, the water stored there has quality influenced by agricultural inputs (Fig. 6).

Although in the studied area there is a visible difference in the morphology of the terrain between the higher topographic point of the zero-order basin (area of superficial water contribution to the wetland) to the center of the wetland (lower topographic point), the application of the DEM proves the importance that an image of high accuracy and resolution has-many wetlands located on the plateau have much softer reliefs, where it is only possible to prove that the wetland is found in low topographic positions through the generation of the very high-resolution DEM.

The subsurface imaging by the ERT technique proves that the wetland acts, when it is flooded, as an area of direct aquifer recharge. This fact makes it a point of high environmental sensitivity since chemical compounds from the superficial water-flow from adjacent areas have the possibility of infiltrating the aquifer and contaminating groundwater.

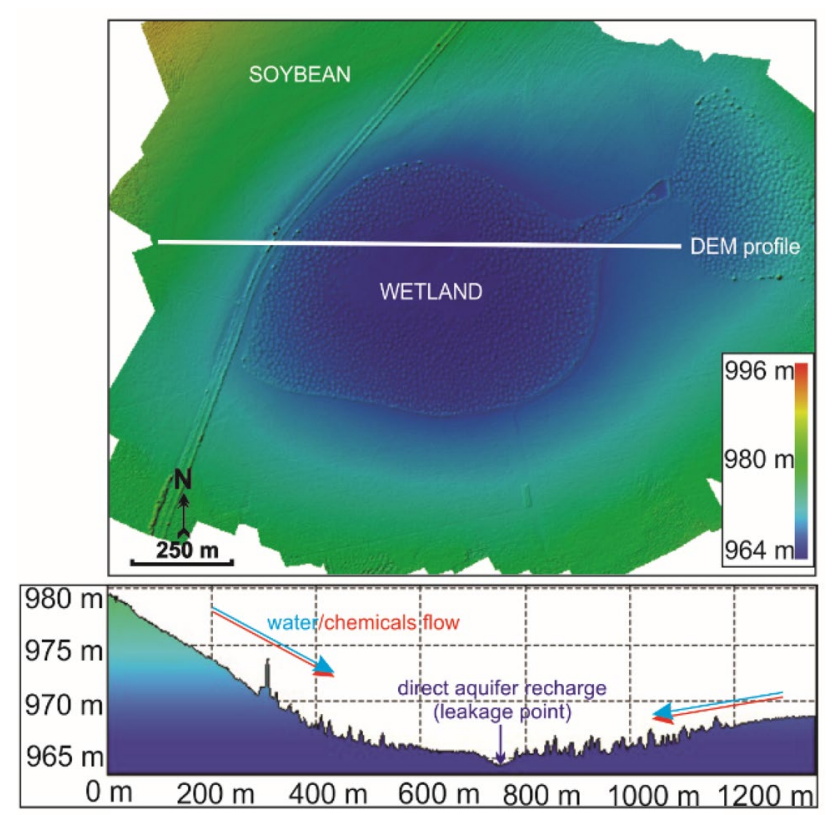

Fig. 6 Digital elevation model (DEM) and its profile of the isolated wetland generated from the first data acquisition (dry season). The profile highlights the water and chemicals preferential flow direction and the point identified as the direct aquifer recharge (leakage point)
Both techniques (UAV and ERT) can be used to identify points of high environmental sensitivity. However, it is important to highlight that UAV imaging must be performed at least twice, in order to contemplate two distinct climatological moments and, thus, provide a temporal understanding of seasonal behavior in the wetland. In this specific case, two images were sufficient because the climatological behavior is marked by a rainy and a dry period, both prominent.

\section{Conclusion}

Wetland soil pedogenesis results of soil change processes that increase bulk density and reduce Ksat in the subsurface, altering the moisture regime. Two flows, one vertical and one lateral were formed from this architecture and they determine the hydrological model of wetland in the catchment. Vertical flow occurs exclusively at the center of the topographic depression and this is where the wetland is characterized as a recharge zone (leakage point). In the saprolite, the existence of another impermeable layer shifts the flow direction laterally towards the river and is characterized as a discharge area.

Although the study focused on one isolated wetland, the hydrological model proposed in this study may represent the whole plateau system considering that Plinthosols dominate in upland wetlands where soil morphology and properties related to waterlogged conditions is repeated in the catchment. This hydrological model is very important to support studies related to the presence and dispersion of contaminants in the area since agriculture dominates the whole area of well-drained soils and for the management of water resources considering the intensification of the use conversion of the land and crop irrigation.

The wetlands in the plateau acts like zero-order basins that effectively contribute to the maintenance of water resources availability. The surface water-storage and the supply of water to the aquifer (leakage point) highlights the importance of their environmental maintenance and the creation of public policies for the preservation of isolated wetlands.

The integrated use of remote sensing techniques of high spatial-temporal resolution (UAV) and subsurface imaging of physical properties of the soil (ERT) allowed the disclosure of points of high environmental sensitivity with non-invasive techniques and with very high-resolution results. The correlation of non-invasive techniques with analyzes of physical soil properties allows not only to validate indirect data but also to bring interconnected results about the hydrological role of wetlands in the local and regional hydrological cycle. The techniques can be widely 
replicated across the plateau in order to better understand wetlands hydrodynamics and reveal their surface and subsurface connections.

Acknowledgements This work was funded by the FAPESP - Fundação de Amparo à Pesquisa do Estado de São Paulo (Processes $n^{\circ}$ 2017/14168-1), the Department of Geology of UNESP—Rio Claro for the availability of the geophysical equipment and the Coordenação de Aperfeiçoamento de Pessoal de Nível Superior (CAPES) for the financial support.

Availability of data and material The data that support the findings of this study are available from the corresponding author, Furlan, L. M., upon reasonable request.

\section{Compliance with ethical standards}

Conflict of interest On behalf of all authors, the corresponding author states that there is no conflict of interest.

Open Access This article is licensed under a Creative Commons Attribution 4.0 International License, which permits use, sharing, adaptation, distribution and reproduction in any medium or format, as long as you give appropriate credit to the original author(s) and the source, provide a link to the Creative Commons licence, and indicate if changes were made. The images or other third party material in this article are included in the article's Creative Commons licence, unless indicated otherwise in a credit line to the material. If material is not included in the article's Creative Commons licence and your intended use is not permitted by statutory regulation or exceeds the permitted use, you will need to obtain permission directly from the copyright holder. To view a copy of this licence, visit http://creativecommons .org/licenses/by/4.0/.

\section{References}

1. Qiao J, Zhu Y, Jia X, Huang $L$ (2018) Estimating the spatial relationships between soil hydraulic properties and soil physical properties in the critical zone $(0-100 \mathrm{~m})$ on the Loess Plateau, China: a state-space modeling approach. CATENA 160:385-393. https://doi.org/10.1016/j.catena.2017.10.006

2. Sparks DL (2005) Toxic metals in the environment: the role of surfaces. Elements 1(4):193-197. https://doi.org/10.2113/gsele ments.1.4.193

3. Bernard M, Boutry S, Lissalde S, Guibaud G, Saüt M, Rebillard JP, Mazzella N (2019) Combination of passive and grab sampling strategies improves the assessment of pesticide occurrence and contamination levels in a large-scale watershed. Sci Total Environ 651:684-695. https://doi.org/10.1016/j.scito tenv.2018.09.202

4. Lin H, Vogel HJ, Phillips J, Fath BD (2015) Complexity of soils and hydrology in ecosystems. Ecol Model 100(298):1-3. https://doi. org/10.1016/j.ecolmodel.2014.11.016

5. Beven K (2015) What we see now: event-persistence and the predictability of hydro-eco-geomorphological systems. Ecol Model 298:415. https://doi.org/10.1016/j.ecolmodel.2014.07.01

6. Tardy Y (1993) Pétrologie des latérites et des sols tropicaux. Masson, Paris

7. Nahon DB (1991) Introduction to the petrology of soils and chemical weathering. Wiley, New York
8. Beauvais A, Ritz M, Parisot JC, Dukhan M, Bantsimba C (1999) Analysis of poorly stratified lateritic terrains overlying a granitic bedrock in West Africa, using 2-D electrical resistivity tomography. Earth Planet Sci Lett 173(4):413-424. https://doi. org/10.1016/S0012-821X(99)00245-9

9. Alaoui A, Lipiec J, Gerke HH (2011) A review of the changes in the soil pore system due to soil deformation: a hydrodynamic perspective. Soil Tillage Res 115:1-15. https://doi.org/10.1016/j. still.2011.06.002

10. Wilding LP, Rehage JA (1985) Pedogenesis of soils with aquic moisture regimes. In: Wetland soils: characterization classification and utilization. International Rice Research Institute, pp 139-157

11. Lucas $Y$, Chauvel A (1992) Soil formation in tropically weathered terrains. In: Handbook of exploration geochemistry. Elsevier Science BV, pp 57-77

12. Bradley C, Gilvear DJ (2000) Saturated and unsaturated flow dynamics in a floodplain wetland. Hydrol Process 14(1617):2945-2958. https://doi.org/10.1002/1099-1085(20001 1/12)14:16/17\%3c2945::AIDHYP128\%3e3.0.CO;2-R

13. Vepraskas MJ, Lindbo DL, Lin H (2012) Redoximorphic features as related to soil hydrology and hydric soils. Hydropedology: synergistic integration of soil science and hydrology. Elsevier, Oxford, pp 143-172

14. Lee S, Yeo I-Y, Lang MW, Sadegui AM, McCarthy GW, Moglen GE, Evenson GR (2018) Assessing the cumulative impacts of geographically isolated wetlands on watershed hydrology using the SWAT model coupled with improved wetland modules. J Environ Manag 223:37-48. https://doi.org/10.1016/j.jenvm an.2018.06.006

15. Rover J, Wright CK, Euliss NH, Mushet DM, Wylie BK (2011) Classifying the hydrologic function of prairie potholes with remote sensing and GIS. Wetlands 31(2):319-327. https://doi. org/10.1007/s13157-011-0146-y

16. Gabrielsen CG, Murphy MA, Evans JS (2016) Using a multiscale, probabilistic approach to identify spatial-temporal wetland gradients. Remote Sens Environ 184:522-538. https://doi. org/10.1016/j.rse.2016.07.034

17. Mitsch WJ, Gosselink JG (1993) Wetland, 2nd edn. Wiley, New York

18. Amendola D, Mutema M, Rosolen V, Chaplot V (2018) Soil hydromorphy and soil carbon: a global data analysis. Geoderma 324:9-17. https://doi.org/10.1016/j.geoderma.2018.03.005

19. Leite MB, Xavier RO, Oliveira PTS, Silva FKG, Matos DMS (2018) Groundwater depth as a constraint on the woody cover in a Neotropical Savanna. Plant Soil 426(1-2):1-15. https://doi. org/10.1007/s11104-018-3599-4

20. Reddy KR, DeLaune RD (2010) Biogeochemistry of wetlands: science and applications. Ecol Eng 36(4):607-608

21. Xu J, Zhuang Q, Fu Y, Huang Y, Sun Z, Liu Z (2019) Spatial distribution, pollution levels, and source identification of heavy metals in wetlands of Suzhou Industrial Park, China. Wetl Ecol Manag 27:743-758. https://doi.org/10.1007/s11273-019-09691 $-2$

22. Fernandes LA, Coimbra AM (2000) Revisão estratigráfica da parte oriental da Bacia Bauru (Neocretáceo). Revista brasileira de Geociências 30(4):717-728

23. Sidle RC, Gomi T, Tsukamoto Y (2018) Discovery of zero-order basins as an important link for progress in hydrogeomorphology. Hydrol Process 32(19):3059-3065. https://doi.org/10.1002/ hyp. 13246

24. FAO (2006) World reference base for soil resources. A framework for international classification, correlation and communication. Rome, Italy. http://www.fao.org/fileadmin/templates/nr/image s/resources/pdf_documents/wrb2007_red.pdf. Accessed 20 Dec 2020 
25. SiBCS Sistema Brasileiro de Classificação de Solos (2013) Centro Nacional de Pesquisa de Solos: Rio de Janeiro. Embrapa Solos, Brasília, Brasil

26. Queiroz AT (2012) Análise e avaliação da demanda e da disponibilidade hídrica nos alto e médio curso do Rio Uberabinha e o abastecimento público em Uberlândia (MG). Dissertation, Federal University of Uberlândia

27. Munsell A (2000) Munsell soil color charts. Gretagmacbeth, New York

28. Embrapa. Empresa Brasileira de Pesquisa Agropecuária (1997) Manual de Métodos de Análise de Solo. Centro Nacional de Pesquisas de Solo, Rio de Janeiro

29. Stoops G, Marcelino V, Mees F (2010) Micromorphological features and their relation to processes and classification: general guidelines and keys. In: Interpretation of micromorphological features of soils and regoliths. Elsevier, pp 15-35

30. Blake GR, Hartge KH (1986) Bulk density. Methods Soil Anal Part 1 Phys Mineral Methods 5:363-375. https://doi.org/10.2136/ sssabookser5.1.2ed.c13

31. Reynolds WD, Elrick DE, Topp GC (1983) A reexamination of the constant head well permeameter method for measuring saturated hydraulic conductivity above the water table 1 . Soil Sci 136(4): 250

32. Soil Moisture Equipment Corp (1991) Guelph permeameter. Operating: Instructions. Santa Barbara

33. Ouédraogo MM, Degré A, Debouche C, Lisein J (2014) The evaluation of unmanned aerial system-based photogrammetry and terrestrial laser scanning to generate DEMs of agricultural watersheds. Geomorphology 214:339-355. https://doi.org/10.1016/j. geomorph.2014.02.016

34. D'Oleire-Oltmanns S, Marzolff I, Peter KD, Ries JB (2012) Unmanned aerial vehicle (AV) for monitoring soil erosion in Morocco. Remote Sens 4(11):3390-3416. https://doi. org/10.3390/rs4113390

35. Dahlin T (1996) 2D resistivity surveying for environmental and engineering applications. First Break 14:7. https://doi. org/10.3997/1365-2397.1996014

36. Loke MH, Barker RD (1996) Rapid least-squares inversion of apparent resistivity pseudosections by a quasi-Newton method 1. Geophys Prospect 44(1):131-152. https://doi. org/10.1111/j.1365-2478.1996.tb00142.x

37. NRCS, USDA (2017) The plants database (http://plants.usda.gov). National Plant Data Team, Greensboro

38. Evans CV, Franzmeier DP (1988) Color index values to represent wetness and aeration in some Indiana soils. Geoderma 41 (34):353-368. https://doi.org/10.1016/0016-7061(88)90070-5

39. Assouline S (2011) Soil surface sealing and crusting. In: Glinski J, Horabik J, Lipiec J (eds) Encyclopedia of agrophysics. Springer, Institute of Agrophysics, Polish Academy of Sciences, Lublin, pp 786-790

40. Rosolen V, Bueno GT, Mutema MCA, Junior IRF, Nogueira G, Chaplot V (2019) On the link between soil hydromorphy and geomorphological development in the Cerrado (Brazil) wetlands. CATENA 176:197-208. https://doi.org/10.1016/j.caten a.2019.01.022

41. Miralles-Mellado I, Cantón Y, Solé-Benet A (2011) Two-dimensional porosity of crusted silty soils: indicators of soil quality in semiarid rangelands? Soil Sci Soc Am J 75(4):1330-1342. https ://doi.org/10.2136/sssaj2010.0283

42. Terzaghi K, Peck RB, Mesri G (1996) Soil mechanics in engineering practice. Wiley, Hoboken

43. Mello VF, Teixeira AH (1967) Mecânica dos solos. Escola de Engenharia, São Carlos

44. Lilienfein J, Wilcke W, Ayarza MA, do Lima SC, Vilela L, Zech W (1999) Annual course of matric potential in differently used savanna Oxisols in Brazil. Soil Sci Soc Am J 63(6):1778-1785. https://doi.org/10.2136/sssaj1999.6361778x

45. Oliveira PTS, Wendland E, Nearing MA, Scott RL, Rosolem R, da Rocha HR (2015) The water balance components of undisturbed tropical woodlands in the Brazilian cerrado. Hydrol Earth Syst Sci 19(6):2899-2910. https://doi.org/10.5194/hessd-11-12987-2014

46. Silva OB, Caria ME, Carrasco-Benavides M, Bertani G, Augusto VMG (2018) Improved albedo estimates implemented in the METRIC model for modeling energy balance fluxes and evapotranspiration over agricultural and natural areas in the Brazilian Cerrado. Remote Sens 10(8):1181. https://doi.org/10.3390/rs100 81181

47. Alemayehu T, Griensven AV, Senay GB, Bauwens W (2017) Evapotranspiration mapping in a heterogeneous landscape using remote sensing and global weather datasets: application to the Mara Basin, East Africa. Remote Sens 9(4):390. https://doi. org/10.3390/rs9040390

48. Dongli S, Qian C, Timm LC, Beskow S, Wei Hu, Caldeira TL, Oliveira LM (2017) Multi-scale correlations between soil hydraulic properties and associated factors along a Brazilian watershed transect. Geoderma 286:15-24. https://doi.org/10.1016/j.geode rma.2016.10.017

49. Vogeler I, Carrick S, Cichota R, Lilburne L (2019) Estimation of soil subsurface hydraulic conductivity based on inverse modelling and soil morphology. J Hydrol 574:373-382. https://doi. org/10.1016/j.jhydrol.2019.04.002

50. Becker R, Gebremichael M, Märker M (2018) Impact of soil surface and subsurface properties on soil saturated hydraulic conductivity in the semi-arid Walnut Gulch experimental watershed. Geoderma 322:112-120. https://doi.org/10.1016/j.geode rma.2018.02.023

51. Sousa RVB, Celligoi A (2009) Monitoramento hidrogeológico como ferramenta de avaliação à degradação dos recursos hídricos: estudo realizado no aterro controlado de Londrina-PR. GEOGRAFIA (Londrina) 18(1):45-63

52. Cosh MH, Jackson TJ, Moran S, Bindlish R (2008) Temporal persistence and stability of surface soil moisture in a semi-arid watershed. Remote Sens Environ 112(2):304-313. https://doi. org/10.1016/j.rse.2007.07.001

53. Tian Z, Lu Y, Ren T, Horton R, Heitman JL (2018) Improved thermo-time domain reflectometry method for continuous insitu determination of soil bulk density. Soil Tillage Res 178:118129. https://doi.org/10.1016/j.still.2017.12.021

54. Fanning DS, Fanning MCB (1989) Soil morphology, genesis and classification. Wiley, New York

55. Biswas A, Si BC (2011) Revealing the controls of soil water storage at different scales in a hummocky landscape. Soil Sci Soc Am J 75(4):1295-1306. https://doi.org/10.2136/sssaj2010.0131

56. Phillips JD, Lorz C (2008) Origins and implications of soil layering. Earth Sci Rev 89(3-4):144-155. https://doi.org/10.1016/j.earsc irev.2008.04.003

57. Furlan LM, Rosolen V, Sales J, Moreira CA, Ferreira ME, Bueno GT, Sousa Coelho CV, Mounier S (2020) Natural superficial waterstorage and aquifer recharge assessment in Brazilian savanna wetland using unmanned aerial vehicle and geophysical survey. J Unmanned Veh Syst 8(3):224-244. https://doi.org/10.1139/ juvs-2020-0004

58. Phillips R, Beeri O (2008) The role of hydropedologic vegetation zones in greenhouse gas emissions for agricultural wetland landscapes. CATENA 72(3):386-394. https://doi.org/10.1016/j. catena.2007.07.007

59. Ozesmi SL, Bauer ME (2002) Satellite remote sensing of wetlands. Wetl Ecol Manag 10(5):381-402. https://doi. org/10.1023/A:1020908432489

60. Osat M, Heidari A, Eghbal MK, Mahmoodi S (2016) Impacts of topographic attributes on soil taxonomic classes and 
weathering indices in a hilly landscape in Northern Iran. Geoderma 281:90-101. https://doi.org/10.1016/j.geode rma.2016.06.020

61. Rapinel S, Fabre E, Dufour S, Arvor D, Mony C, Hubert-Moy L (2019) Mapping potential, existing and efficient wetlands using free remote sensing data. J Environ Manag 247:829-839. https ://doi.org/10.1016/j.jenvman.2019.06.098

62. Keller GV, Frischknecht FC (1966) Electrical methods in geophysical prospecting. Pergamon Press, Oxford

63. Telford WM, Geldart LP, Sheriff RE, Keys DA (2004) Applied geophysics. Cambridge University Press, Cambridge

64. Loke MH (2004) Tutorial: 2-D and 3-D electrical imaging surveys. Geoelectrical course pdf

65. Baldwin D, Naithani KJ, Lin H (2017) Combined soil-terrain stratification for characterizing catchment-scale soil moisture variation. Geoderma 285:260-269

66. Greer BM, Burbey TJ, Zipper CE, Hester ET (2017) Electrical resistivity imaging of hydrologic flow through surface coal mine valley fills with comparison to other landforms. Hydrol Process 31(12):2244-2260. https://doi.org/10.1002/hyp.11180

67. Appels WM, Graham CB, Freer JE, McDonnell JJ (2015) Factors affecting the spatial pattern of bedrock groundwater recharge at the hillslope scale. Hydrol Process 29(21):4594-4610. https:// doi.org/10.1002/hyp.10481

68. Freer J, McDonnell JJ, Beven KJ, Peters NE, Burns DA, Hooper RP, Kendall C (2002) The role of bedrock topography on subsurface storm flow. Water Resour Res 38(12):1-5. https://doi. org/10.1029/2001WR000872

69. Weiler M, McDonnell J (2004) Virtual experiments: a new approach for improving process conceptualization in hillslope hydrology. J Hydrol 285(1-4):3-18. https://doi.org/10.1016/ S0022-1694(03)00271-3

70. Fenstermacher DE, Rabenhorst MC, Lang MW, McCarty GW, Needelman BA (2014) Distribution, morphometry, and land use of Delmarva Bays. Wetlands 34(6):219-1228. https://doi. org/10.1007/s13157-014-0583-5

71. Hong H, Gu Y, Li R, Zhang K, Li Z (2010) Clay mineralogy and geochemistry and their palaeoclimatic interpretation of the Pleistocene deposits in the Xuancheng section, southern China. J Quat Sci 25(5):662-674. https://doi.org/10.1002/jqs.1340

72. Salgado-Labouriau ML, Barberi M, Ferraz-Vicentini KR, Parizzi MG (1998) A dry climatic event during the late quaternary of tropical Brazil. Rev Palaeobot Palynol 99(2):115-129. https://doi. org/10.1016/S0034-6667(97)00045-6

73. Barberi M, Salgado-Labouriau ML, Suguio K (2000) Paleovegetation and paleoclimate of "Vereda de Águas Emendadas", central Brazil. J S Am Earth Sci 13(3):241-254. https://doi.org/10.1016/ S0895-9811(00)00022-5
74. Bijos NR, Eugênio CUO, Mello TDRB, de Souza GF, Munhoz CBR (2017) Plant species composition, richness, and diversity in the palm swamps (veredas) of Central Brazil. Flora 236:94-99. https ://doi.org/10.1016/j.flora.2017.10.002

75. Thompson JA, Bell JC, Butler CA (2001) Digital elevation model resolution: effects on terrain attribute calculation and quantitative soil-landscape modeling. Geoderma 100(1-2):67-89. https ://doi.org/10.1016/S0016-7061(00)00081-1

76. Ministério do Meio Ambiente (MMA) (2011). Plano de ação para prevenção e controle do desmatamento e das queimadas: Cerrado. Brasília, pp 200

77. Terrabrasilis (2020) Instituto Nacional de Pesquisas Espaciais. http://terrabrasilis.dpi.inpe.br/. Accessed 22 June 2020

78. Junk WJ, Na S, Finlayson CM, Gopal B, Kvet J, Mitchell SA, Mitsch WJ, Robarts RD (2013) Current state of knowledge regarding the world's wetlands and their future under global climate change: a synthesis. Aquat Sci 75:151-167. https://doi.org/10.1007/s0002 7-012-0278-z

79. Rosolen V, de Oliveira DA, Bueno GT (2015) Vereda and Murundu wetlands and changes in Brazilian environmental laws: challenges to conservation. Wetl Ecol Manag 23(2):285-292. https ://doi.org/10.1007/s11273-014-9380-4

80. de Moraes PPF, Horn AH (2010) Teores dos metais pesados $\mathrm{Cr}, \mathrm{Cd}$ e $\mathrm{Zn}$ em perfis de solos de veredas da bacia do Rio do Formoso, município de Buritizeiro, Minas Gerais. Geonomos. https://doi. org/10.18285/geonomos.v18i2.75

81. Rosolen V, De-Campos AB, Govone JS, Rocha C (2015) Contamination of wetland soils and floodplain sediments from agricultural activities in the Cerrado Biome (State of Minas Gerais, Brazil). CATENA 128:203-210. https://doi.org/10.1016/j.caten a.2015.02.007

82. Ribeiro BT, Nascimento DC, Curi N, Guilherme LRG, Costa ETDS, Lopes G, Carneiro JP (2019) Assessment of trace element contents in soils and water from Cerrado Wetlands, Triângulo Mineiro Region. Revista Brasileira de Ciência do Solo. https:// doi.org/10.1590/18069657rbcs20180059

83. Yeo IY, Lang MW, Lee S, McCarty GW, Sadeghi AM, Yetemen O, Huang C (2019) Mapping landscape-level hydrological connectivity of headwater wetlands to downstream waters: a geospatial modeling approach-part 1. Sci Total Environ 653:1546-1556. https://doi.org/10.1016/j.scitotenv.2018.11.238

Publisher's Note Springer Nature remains neutral with regard to jurisdictional claims in published maps and institutional affiliations. 